\title{
SURVEY PELAKSAAN PEMBELAJARAN PJOK SECARA DARING PADA MASA PANDEMI COVID-19
}

\author{
Nurul Raodatun Hasanah¹, I Putu Panca Adi², I Gede Suwiwa³ \\ 1,2,3 Jurusan Pendidikan Olahraga, Universitas Pendidikan Ganesha, Singaraja \\ E-mail: nurulraodatun13@gmail.com11, pancaadi@undiksha.ac.id², gede.suwiwa@undiksha.ac.id³ \\ DOI: https://doi.org/10.36526/kejaora.v6i1.1295
}

\begin{abstract}
ABSTRAK
Penelitian ini bertujuan untuk mengetahui proses pelaksanaan pembelajaran PJOK secara daring pada masa pandemic covid-19 dikelas VIII SMP Negeri 4 tejakula. Jenis penelitian ini yaitu deskriptif kuantitatif berdasarkan analisis data pada penilaian katagori, pelaksanaan pembelajaran PJOK memperoleh nilai 62 dengan katagori cukup baik. dan dilihat dari pembelaran pendahuluan, pembelajaran inti, serta pembelajaran penutup sehingga rata-rata keseluruhan perolehan nilai yang di dapatkan 62 berada pada katagori cukup baik. hasil penelitian dapat disimpulkan bahwa survey pelaksanaan pembelajaran PJOK secara daring pada masa pandemi Covid-19 dikelas VIII SMP Negeri 4 tejakula tahun pelajaran 2020/2021. berada pada katagori cukup baik Diharapkan agar menigkatkan proses pembelajaran pendidikan jasmani, Olahraga dan Kesehatan di masa pandemi Covid-19 sehingga dapat meningkatkan pengetahuan, keterampilan diri dan mencetak prestasi meskipun belajar dirumah.
\end{abstract}

Kata Kunci: Learning CHD, Covid-19 online learning.

\section{PENDAHULUAN}

Pendidikan di sekolah sangat penting utamanya terdapat pada mata pelajaran yang harus dipelajari oleh peserta didik dan salah satunya adalah pendidikan jasmani olahraga dan kesehatan PJOK yang ada di sekolah. Menurut Husdarta (2009) pada proses pembelajaran PJOK ditekankan bahwa pengembangan individu secara menyeluruh, dalam arti pengembangan yang mencakup perkembangan fisik mental intelektual dan perkembangan sosial. Sejak surat keputusan dari Menteri Pendidikan dan Kebudayaan terbit mengenai upaya pencegahan dan penyebaran virus corona atau Covid-19, semua kegiatan pembelajaran secara langsung mulai diliburkan sementara waktu. Pembelajaran daring dilakukan sebagai pilihan stategis dalam memutus penyembaran wabah covid-19 (Yudiawan, 2020). Pandemi Covid 19 atau masuknya virus Corona ke Indonesia telah mengubah proses pembelajaran sekolah di hampir sebagian besar wilayah Indonesia menjadi Pendidikan Jarak Jauh (PJJ), belajar dari rumah, atau School from Home (SFH)
(Megawanti et al., 2020). Kegiatan pembelajaran secara langsung yang dilaksanakan oleh guru perlahan terkikis dan tergantikan dengan berbagai aplikasi pembelajaran daring yang dapat memberi ruang intraksi langsung antara guru dengan peserta didik tanpa harus bertemu secara langsung. Adanya gangguan dalam proses pembelajaran menyebabkan terjadinya beberapa perubahan terhadap peserta didik yang pada akhirnya berpengaruh terhadap motivasi belajarnya (Cahyani et al., 2020). Guru dan peserta didik, bahkan orang tua dipaksa untuk beradaptasi secara cepat dengan metode daring, di tengah situasi yang sedang terjadi saat ini, metode daring adalah solusi yang paling tepat untuk dilakukan. Meski sekolah diliburkan, tetapi tuntutan dalam proses pembelajaran masih dapat terlaksana dan tercapai. pembelajaran secara daring adalah salah satu alternatif yang dapat mengatasi masalah tersebut (Sadikin \& Hamidah, 2020a).

Minimnya pengetahuan teknologi guru, peserta didik dan orang tua menjadi salah satu permasalahan pengaplikasian 
Jurnal Kejaora: Jurnal Kesehatan Jasmani dan Olah Raga

ISSN: 2541-5042 (Online)

ISSN: 2503-2976 (Print)

Volume 6 Nomor 1, Edisi April 2021

metode daring tersebut, guru dan peserta didik diminta untuk beradaptasi dan menguasai berbagai aplikasi yang mendukung pembelajaran daring dengan cepat. Lemahnya jaringan internet dirasa menjadi kendala yang sering dialami oleh para guru. Hal ini terutama bagi guru dan peserta didik yang tinggal di daerah pedesaan atau pedalaman akan sangat sulit untuk mendapatkan akses internet. Internet merupakan faktor penting terlaksanakannya pembelajaraSn daring. Latar belakang peserta didik juga perlu diperhatikan sebelum diberlakukannya metode daring tersebut. Tidak semua peserta didik berasal dari keluarga dan lingkungan yang baik-baik saja. Terdapat peserta didik yang berasal dari anak-anak broken home, lingkungan tempat tinggal yang sangat tidak mendukung, serta anak-anak dari keluarga yang kurang mampu bahkan anak-anak dari keluarga yang kurang mendukung kegiatan pendidikan.

Proses pembelajaran merupakan suatu proses yang didalamnya terdapat kegiatan interaksi antara guru dengan peserta didik dan adanya komunikasi timbal balik yang berlangsung dalam situasi edukatif untuk mencapai tujuan belajar. Sistem pembelajaran daring merupakan sistem pembelajaran tanpa tatap muka secara langsung antarguru dan peserta didik, melainkan secara online yang menggunakan jaringan internet (Asmuni, 2020). Educators must also maximize their teaching time so that it requires learning models such as e-learning and blended learning to meet the loss of teaching time due to other activities that must be done by the teacher besides teaching (Huda et al., 2019).

Berdasarkan pendapat diatas, pembelajaran merupakan suatu upaya dalam proses pembelajaran yang berjalan secara efektif dan efisien, sehingga terjadi perubahan prilaku kearah yang lebih baik untuk mencapai tujuan yang diharapkan. PJOK pada dasarnya merupakan bagian integral dari sistem pendidikan secara keseluruhan, bertujuan untuk mengembangkan aspek kesehatan, kebugaran jasmani, keterampilan berpikir kritis, stabilitas emosional, keterampilan social, penalaran dan tindakan moral melalui

aktivitas jasmani dan olahraga Berdasarkan pendapat di atas, bahwa PJOK merupakan bagian integral untuk mengembangkan seluruh aspek aktivitas fisik, mental dan emosional yang disajikan sebagai kegiatan dalam proses pendidikan.

Dalam proses pembelajaran PJOK, guru diharapkan mampu memahami dan menerapkan sistematika pembelajaran guna mencapai tujuan hasil belajar yang optimal. menurut (Marheni et al., 2020) memberikan pemahaman dan pengetahuan kepada siswa untuk melaksanakan dan kembali meningkatkan motivasi belajar khususnya PJOK untuk mengurangi permasalahan psikologi atau bahkan melawan civus dengan meningkatkan imunitas tubuh melalui pembelajaran PJOK di sekolah. Sistematika pembelajaran merupakan proses yang menjadi satu kesatuan kerja yang tidak dapat dipisahkan dalam pembelajaran dimana berlaku dalam semua jenis pelajaran PJOK. Dimana tujuan dari sistematika pembelajaran ini adalah agar semua penyampaian materi, proses pembelajaran peserta didik dapat maksimal dan mudah dalam memahami seluruh materi yang diberikan dalam proses pembelajaran.

Hasi belajar PJOK adalah hasil tertinggi yang diperoleh dari proses pembelajaran PJOK yang berupa perubahan sikap dan penampilan dari individu dengan cara mengamati, menirukan, mencoba dan mendengarkan petunjuk serta pengarahan.

Dari beberapa pengertian tersebut, hasil belajar adalah tercapainya suatu nilai dari setiap kompetisi dasar baik pengetahuan, afektif, maupun keterampilan yang diperoleh dari kegiatan mendengarkan, mengamati, menirukan, mencoba, mengikuti petunjuk dan pengarahan yang mengakibatkan perubahan tingkah laku yang disebabkan oleh pengalaman. While the structure and organization of support services for international students can vary greatly in function, role, and reporting line, universities in the US, UK, and Australia commonly have dedicated offices designed to support students in their academic, cultural and social transition to campus (Ammigan, 2018).

Mengantisipasi dan mengurangi jumlah penderita virus ini di Indonesia sudah 
Jurnal Kejaora: Jurnal Kesehatan Jasmani dan Olah Raga

ISSN: 2541-5042 (Online)

ISSN: 2503-2976 (Print)

Volume 6 Nomor 1, Edisi April 2021

dilakukan di seluruh daerah. Diantaranya dengan memberikan kebijakan membatasi aktivitas keluar rumah, kegiatan sekolah dirumahkan, bekerja dari rumah, bahkan kegiatan beribadah pun dirumahkan. Hal ini sudah menajdi kebijakan pemerintah berdasarkan pertimbangan-pertimbangan yang sudah dianalisa dengan maksimal.

Hampir semua kegiatan dirumahkan , dan kebijakan ini disebut dengan lockdown. Lockdown dapat membantu mencegah penyebaran virus, sehingga masyarakat yang berada di suatu wilayah tersebut diharapkan dapat tehindar dari virus. Kebijakan ini hanya dapat dilakukan oleh pemerintah, dengan terlebih dahulu melakukan pemeriksaan ketat sebelumnya ke beberapa wilayah dan mempertimbangkan konsekuensinya secara matang, baik secara ekonomi maupun sosial. Kegiatan lockdown merupakan bagian dari peraturan perundang-undangan yang tertuang dalan Undang-Undang Nomor 6 Tahun 2018 tentang Kekarantinaan Kesehatan yang membahas Kekarantinaan Kesehatan di Pintu Masuk dan Wilayah dilakukan melalui kegiatan pengamatan penyakit dan faktor resiko Kesehatan Masyarakat terhadap alat angkut, orang, barang dan lingkungan, serta respons terhadap Kedaruratan Kesehatan Masyarakat dalam bentuk tindakan Kekarantinaan Kesehatan.

Pandemi ini memaksa masyarakat untuk mengubah makna pola hidup dan kehidupan sehari-hari yang berdampak pada semua aspek kehidupan. Dampak covid-19 ini memaksa semua kebijakan sosial distancing atau physical distancing ( menjaga jarak fisik ) dilakukan untuk meminimalisir dan mencegah penyebaran virus. Menteri Pendidikan dan Kebudayaan (Mendikbud) Nadiem Anwar mengatakan bahwa prinsip dikeluarkannya kebijakan pendidikan di masa Pandemi Covid-19 adalah dengan memprioritaskan kesehatan dan keselamatan peserta didik, pendidik, tenaga kependidikan, keluarga, dan masyarakat (Wulandari \& Agustika, 2020). Belajar dari pengalaman virus yang telah terjadi sebelum adanya Covid-19. Telah banyak ditemukan ramuan atau sentuhan yang telah dilakukan untuk mengatasi dan meningkatkan kembali

keinginan atau motivasi siswa untuk belajar di sekolah (Marheni et al., 2020). Masyarakat harus melihat perubahan-perubahan di bidang ekonomi, sosial, politik hingga pendidikan ikut berduka di tengah-tengah krisis akibat penyebaran covid-19 (Widyaningsih, n.d.). Penyebaran virus corona ini mengakibatkan tenaga dan siswa menjadi korban dari wabah virus ini. Terutama dampak yang dirasakan oleh siswa adalah dampak negatif karena mereka "dipaksa" untuk melakukan pembelajaran dari rumah (Simatupang et al., 1981).

Dalam perkembangan teknologi informasi dan komunikasi telah membawa perubahan yang sangat besar bagi kemajuan dunia pendidikan. studi tentang pembelajaran daring diera covid-19 memiliki dua kecenderungan.

Pertama, kajian tentang implementasi pelaksanaan pembelajaran daring (Yudiawan, 2020). Seiring dengan perkembangan tersebut metode pembelajaran juga banyak mengalami perkembangan, baik metode pembelajaran secara personal, media pembelajaran ataupun proses pembelajaran. Bentuk dari perkembangan teknologi informasi yang diterapkan di dunia pendidikan adalah $E$ Learning (pembelajaran secara elektronik). Elearning merupakan sebuah inovasi teknologi yang mempunyai kontribusi sangat besar terhadap perubahan proses pembelajaran, dimana proses belajar tidak lagi hanya mendengarkan uraian materi dari guru tetapi peserta didik juga melakukan aktivitas lain seperti mengatasi keterbatasan waktu dan ruang antara peserta didik dan tenaga pengajar mengakses bahan-bahan belajar setiap saat dan berulang-ulang meningkatkan kuantitas peserta didik, dapat berkomunikasi baik sesama peserta didik, peserta didik dengan pengajar, ataupun kelompok lain diluar institusi sekolah misalnya melalui web, chatting dan email. Inovasi dan perkembangan teknologi turut mengubah wajah pendidikan global. Menurut Mahardika \& Heryanda (2020) "model pembelajaran semisal pembelajaran dalam jaringan (elearning), mobile learning (m-learning), hybrid learning, dan distance learning merupakan contoh dari bagaimana teknologi turut 
Jurnal Kejaora: Jurnal Kesehatan Jasmani dan Olah Raga

ISSN: 2541-5042 (Online)

ISSN: 2503-2976 (Print)

Volume 6 Nomor 1, Edisi April 2021

mengubah paradigma pendidikan". Pembelajaran daring kurang efektif dilakukan, dikarenakan belum ada persiapan maksimal dari segi regulasi, pelaksana dilapangan, dan juga siswa, serta berbagai infrastruktur pendukung pembelajaran daring, oleh karena itu peneliti memiliki keinginan untuk menguji tingkat efektifitas pembelajaran, dikarenakan tidak boleh ada muatan pembelajaran yang hilang ditengah pandemi ini (Hamdani \& Priatna, 2020).

Internet sebagai salah satu sumber belajar telah melahirkan konsep daring. Daring merupakan bentuk singkatan dari kata "dalam jaringan" (online), yang dapat diartikan sebagai segala sesuatu yang berhubungan dengan teknologi dan media internet. Dengan demikian daring adalah sebuah metode baru penyajian informasi dan fakta dengan menggunakan bantuan atau perantara teknologi internet. Daring merupakan sebuah inovasi teknologi yang mempunyai kontribusi sangat besar terhadap perubahan proses pembelajaran, dimana proses belajar tidak lagi hanya mendengarkan uraian materi dari guru tetapi peserta didik juga melakukan aktivitas lain seperti mengatasi keterbatasan waktu dan ruang antara peserta didik dan tenaga pengajar, mengakses bahan-bahan belajar setiap saat dan berulang-ulang, meningkatkan kuntitas peserta didik, dapat berkomunikasi baik sesama peserta didik, peserta didik dengan pengajar, atau kelompok lain di luar institusi sekolah misalnya melalui web, chatting dan email. Pelaksanaan aktivitas belajar dirumah dengan media daring menuntut mahasiswa menguasai media yang beragam (Hasanah et al., 2020). Dengan daring (online) peserta didik dapat mempelajari materi bahan ajar yang dapat divisualisasikan dalam berbagai format atau bentuk yang lebih dinamis dan interaktif atau peserta didik akan termotivasi untuk terlibat lebih jauh dalam proses pembelajaran tersebut.

Google form adalah salah satu aplikasi daring inovasi dari Google Docs untuk membuat pertanyaan berupa kuisoner ataupun formulir pendaftaran sebuah acara secara online melalui google. Kelebihan dari platform milik google ini adalah pengelola

data yang sudah terinput nantinya bisa dikelola menjadi sebuah diagram. Sehingga pemilik form bisa mengelola hasil data yang sudah diperoleh dengan sangat mudah. Google form atau yang disebut dengan google formulir adalah alat yang berguna untuk membantu merencanakan acara, mengrim survei, memberikan peserta didik atau orang lain kuis, atau mengumpulkan informasi yang mudah dengan cara yang efisien. Form juga dapat dihubungkan ke spreadsheet. Jika spreadsheet terkait dengan bentuk, tanggapan otomatis akan dikirimkan ke spredsheet. Jika tidak pengguna dapat melihat di "Ringkasan Tanggapan" halaman dapat diakses dari menu. Proses pembelajaran dapat berjalan baik dengan teknologi informasi yang sudah berkembang pesat diantaranya E-learning, Google Class, Whatsapp, Zoom serta media informasi lainnya (Sari \& Sutapa, 2020).

Manfaat dari goole form dapat mendistribusi dan tabulasi online dan real time, 50 orang dapat bekerja dalam satu berkas dalam satu waktu, setiap perubahan disimpan secara otomatis, aman untuk menyimpan berkas penting atau tugas tidak takut hilang, rusak maupun terkena virus. Untuk memulai membuat form online harus menentukan form apa yang akan dibuat, banyak kegunaan form yang bisa dipakai, diantaranya form untuk mendapatkan informasi kontak, form untuk menentukan waktu, form untuk undangan pesta, form pendaftaran, form lamaran kerja, form untuk masukan, form evaluasi, dan untuk survey mengisi kuesioner.

Pada penelitian ini google form digunakan untuk mensurvey pelaksanaan pembelajaran PJOKsecara daring dengan cara peserta didik diminta untuk mengisi kuesioner yang dibagikan kepada seluruh responden dalam bentuk google form sesuai kondisi peserta didik pada setiap butir pertanyaan, pertanyaan yang telah disiapkan sebanyak 20 butir pertanyaan yang wajib di isi. Selanjutnya data yang terkumpul dianalisi untuk dideskripsikan.

Komponen yang terdapat dalam kuesioner terdiri atas beberapa pertanyaan yaitu informasi tentang proses pembelajaran secara daring, (1) Apakah dilaksanakan 
Jurnal Kejaora: Jurnal Kesehatan Jasmani dan Olah Raga

ISSN: 2541-5042 (Online)

ISSN: 2503-2976 (Print)

Volume 6 Nomor 1, Edisi April 2021

pembelajaran daring atau tidak; (2) Media apakah yang digunakan untuk proses pembelajaran daring; (3) Bagaimana informasi yang didapatkan secara daring; (4) apakah proses pembelajaran PJOK secara daring terlaksana dengan baik; (5) apakah sistem pembelajaran daring mempermudah proses pembelajaran PJOK; (6) apakakah terdapat hambatan dalam proses pembelajaran daring pada mata pelajaran PJOK. Adapun data sebaran responden pada google form pada gambar berikut.

Hasil penelitian yang relevan dengan penelitian ini adalah penelitian yang dilakukan oleh (1) Jamaluddin et al., (2020) menemukan bahwa metode penelitian menggunakan metode survey dengan mengajukan pertanyaan sebanyak 9 pertanyaan terhadap 265 orang responden, ditemukan $99,6 \%$ responden melakukan pembelajaran daring, dan $86 \%$ dilaksanakan sesuai jadwal perkuliahan ditetapkan oleh fakultas. Informasi yang diperoleh melalui pembelajaran daring cukup diterima oleh mahasiswa (65\%). Lebih dari $60 \%$ responden terbiasa melakukan pembelajaran daring sehingga sebanyak $50 \%$ menyatakan bahwa sistem daring dapat mempermudah proses pembelajaran. (2) Sadikin \& Hamidah, (2020b) pembelajaran daring yang dimaksud dalam penelitian ini adalah pembelaran yang menggunakan media pembelajaran yang dapat diakses menggunakan layanan internet. Penelitian dilakukan dengan terlebih dahulu mengadakan survey kepada mahasiswa mengenai penerapan pembelajaran daring. Survey di sebarka menggunakan google form yang diberikan kepada mahasiswa melalui pesan WhatsApp. Ada 96 subjek yang telah memberikaan respon terhadap survey yang di sebarkan.

Penelitian ini merupakan penelitian kuantitatif deskriptif untuk mengetahui gambaran efektivitas pembelajaran daring pada mata pelajaran Pendidikan Jasmani Olahraga dan Kesehatan (PJOK).

Berdasarkan kerangka berfikir diatas, dapat di ajukan hipotesis penelitian deskriptif ini ialah proses pembelajaran PJOK secara daring dapat terlaksana dengan cukup baik pada masa pandemi covid-19 di kelas VIII SMP 4 Tejakula.

\section{METODE}

Penelitian ini merupakan penelitian deskriptif kuantitatif dengan jenis penelitian survey. Menggunakan teknik analisis data deskriptif dengan presentase dari jawaban peserta didik. Keseluruhan data berupa angket yang berhasil dikumpulkan kemudian dianalisis dengan menggunakan presentase. Analisis tersebut dilakukan untuk mengetahui hasil pembelajaran PJOK pada peserta didik kelas VIII SMP Negeri 4 Tejakula dalam mengikuti pembelajaran PJOK di masa pandemi covid-19. Instrumen yang digunakan berupa angket terdiri dari pernyaatn positif dan negatif, tingkat kesetujuan responden diklarifikasi yaitu Sangat Baik (SB), Baik (B), Cukup Baik (CB), Kurang Baik (KB) Sangat Kurang Baik (SKB). Instrumen yang digunakan berupa angket akan diuji reliabilitas dan validasinya dengan melakukan uji ahli.

Analisis deskriptif yang digunakan untuk mengetahui survey pelaksanaan pembelajaran yang berdasarkan deskriptif frekuensi, sehingga diketahui frekuensi, persentase, dan nilai dengan interval kategori pada tabel di bawah ini:

Tabel 1. Skala PenilaianKategori

\begin{tabular}{llll}
\hline No & Kriteria & Interval Nilai & Katagori \\
\hline 1. & $M_{i}+1,5 . S D_{i} \leq M_{i}+3,0 S D_{i}$ & $80-100$ & Sangat Baik \\
\hline 2. & $M_{i}+0,5 S_{i} \leq M_{i}+1,5 . S_{i}$ & $67-79$ & Baik \\
\hline 3. & $M_{i}-0,5 D_{i} \leq M_{i}+0,5 S D_{i}$ & $54-66$ & Cukup Baik \\
\hline 4. & $M_{i}-1,5 D_{i} \leq M_{i}-0,5 S D_{i}$ & $41-53$ & Kurang Baik \\
\hline 5. & $M_{i}-0,5 S D_{i} \leq M_{i}-1,5 S D_{i}$ & $28-40$ & Sangat Kurang Baik \\
\hline
\end{tabular}




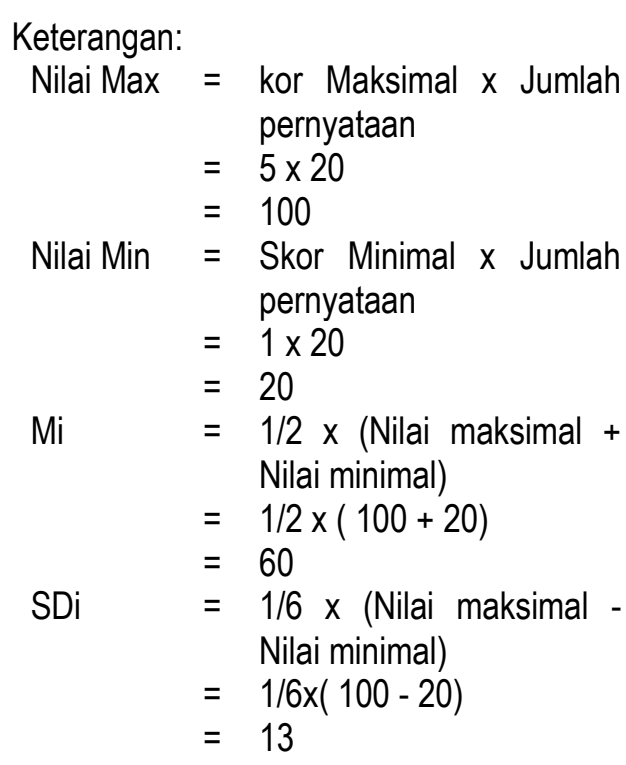

\section{HASIL DAN PEMBAHASAN}

Jika dilihat dari peneliti sebelumnya, Hasil penelitian yang relevan dengan penelitian ini adalah penelitian yang dilakukan oleh (1) Jamaluddin et al., (2020) menemukan bahwa metode penelitian menggunakan metode survey dengan mengajukan pertanyaan sebanyak 9 pertanyaan terhadap 265 orang responden, ditemukan $99,6 \%$ responden melakukan pembelajaran daring, dan $86 \%$ dilaksanakan sesuai jadwal perkuliahan ditetapkan oleh fakultas. Informasi yang diperoleh melalui pembelajaran daring cukup diterima oleh mahasiswa $(65 \%)$. Lebih dari $60 \%$ responden terbiasa melakukan pembelajaran daring sehingga sebanyak $50 \%$ menyatakan bahwa sistem daring dapat mempermudah proses pembelajaran. (2) Sadikin \& Hamidah, (2020b) pembelajaran daring yang dimaksud dalam penelitian ini adalah pembelaran yang menggunakan media pembelajaran yang dapat diakses menggunakan layanan internet. Penelitian dilakukan dengan terlebih dahulu mengadakan survey kepada mahasiswa mengenai penerapan pembelajaran daring. Survey di sebarka menggunakan google form yang diberikan kepada mahasiswa melalui pesan WhatsApp. Ada 96 subjek yang telah memberikaan respon terhadap survey yang di sebarkan. Hasil survey kemudian di kelompokkan kedalam tiga kategori respon mahasiswa: 1) Setuju dengan penerapan pembelajaran daring; 2) Tidak setuju dengan penerapan pembelajaran daring; 3) Ragu dengan pelaksanaan pembelajaran daring, (3) Wulandari \& Agustika, (2020) hasil penelitian ini menunjukan bahwa persepsi mahasiswa terhadap pembelajaran daring bersifat positif artinya mahasiswa memberikan respons yang baik dan positif tentang pembelajaran secara daring. Adapun rincian hasil penelitiannya adalah sebagai berikut: 1) kompetensi dosen sebesar $67,28 \%$ berada pada kriteria positif, 2) proses dan media pembelajaran sebesar $73,5 \%$ berada pada kriteria positif, 3) sarana dan prasarana sebesar $44,3 \%$ berada pada kriteria positif, dan 4) kondisi fisiologis sebesar $46,2 \%$ berada pada kriteria positif. Walaupun berada pada kategori positif namun terdapat porsentase yang cukup tinggi mencirikan pembelajaran daring selama masa pandemi covid-19 sangat dramatik dilihat dari hasil wawancara dengan mahasiswa.

Jadi peneliti menggunakan servey pelaksanaan pembelajaran PJOK ini karna dilihat dari beberapa peneliti yang terlebih dahulu dengan menggukan survey dapat membantu jalannya penelitian tersebut.

$\bar{x}=\frac{\sum f}{n}$
$\bar{x}=\frac{4961}{80}$
$=62$

Berdasarkan hasil skala penilaian katagori survey pelaksanaan pembelajaran PJOK secara daring pada masa pandemic covid-19 dikelas VIII SMP Negeri 4 Tejakula tahun pelajaran 2020/2021 Berada pada katagori cukup baik, dengan interval penilaian 62.

Tujuan dari penelitian ini adalah untuk mengetahui pelaksanaan pembelajaran PJOK secara daring pada masa pandemic covid-19 di kelas VIII smp tejakula. Berdasarkan analisis data pada interval katagori, pelaksanaan pembelajaran PJOK memperoleh nilai 62 Angka tersebut apabila dilihat pada skala interval katagori penilaian kategori tergolong cukup baik Melihat hasil tersebut dapat disimpulkan bahwa pelaksanaan pembelajaran PJOK secara daring pada masa pandemic covid-19 termasuk kedalam katagori baik, dan dilihat 
Jurnal Kejaora: Jurnal Kesehatan Jasmani dan Olah Raga

ISSN: 2541-5042 (Online)

ISSN: 2503-2976 (Print)

Volume 6 Nomor 1, Edisi April 2021

dari garis besarnya pendahuluan, inti, dan penutup pembelajaran sudah berjalan dengan cukup baik.

Tabel 2. Rata-rata Keselurahan Indikator

\begin{tabular}{llll}
\hline no & Indikator & $\begin{array}{l}\text { Rata- } \\
\text { rata }\end{array}$ & Kategori \\
\hline 1 & $\begin{array}{l}\text { Pembelajaran } \\
\text { Pendahuluan }\end{array}$ & 3,25 & Baik \\
\hline 2 & $\begin{array}{l}\text { Pembelajaran } \\
\text { Inti }\end{array}$ & 2,99 & Baik \\
\hline 3 & $\begin{array}{l}\text { Pembelajran } \\
\text { Penutup }\end{array}$ & 3,16 & Baik \\
\hline $\begin{array}{l}\text { Rata-rata } \\
\text { Keseluruhan } \\
\text { Indikator }\end{array}$ & 3,14 & Baik \\
\hline
\end{tabular}

Hasil penelitian ini mempunyai implikasi praktis bagi pihak-pihak yang terkait, yaitu : hasil penelitian menjadi tolak ukur untuk mengetahui survey pelaksanaan pembelajaran PJOK secara daring pada masa pandemic covid -19 dikelas VIII SMP Negeri 4 tejakula tahun ajaran 2020/2021.

Dengan hasil penelitian ini dapat digunakan sebagai acuan bagi sekolah dan guru untuk mengontrol pelaksanaan pembelajaran peserta didik sebagai pendukung keberhasilan proses pembelajaran di saat pembeljaran daring.

\section{KESIMPULAN}

Berdasarkan kesimpulan dari survey pelaksanaan pembelajaran PJOK secara daring pada masa pandemic covid -19 kelas VIII SMP Negeri 4 tejakula berada pada kategori cukup baik, dengan saran yang dapat diberikan yakni bagi peserta didik diharapkan dapat meningkatkan pengetahuan, keterampilan diri, dan berprestasi meskipun belajar dirumah khususnya pada pelajaran pendidikan jasmani, olahraga dan kesehatan, lalu bagi sekolah diharapkan mampu meningkatkan dan menyampaikan proses pembelajarandengan lebih baik lagi agar proses pembelajaran khusunya pembelajaran PJOK secara daring dapat membuat peserta didik termotivasi dalam mengikuti pembelajaran sehingga tidak mudah bosan, selanjutnya bagi peneliti diharapkan dapat melanjutkan penelitian dengan populasi yang

lebih besar dan variabel yang beragam agar hasil yang diperoleh dalam penelitian lebih objektif.

\section{DAFTAR PUSTAKA}

Ammigan, R. (2018). Improving the Student Experience: Learning From a Comparative Study of International Student Satisfaction. Journal of Studies in International Education, 22(4), 283301.

https://doi.org/10.1177/102831531877 3137

Asmuni, A. (2020). Problematika Pembelajaran Daring di Masa Pandemi Covid-19 dan Solusi Pemecahannya. Jurnal Paedagogy, 7(4), 281. https://doi.org/10.33394/jp.v7i4.2941

Cahyani, A., Listiana, I. D., \& Larasati, S. P. D. (2020). Motivasi Belajar Siswa SMA pada Pembelajaran Daring di Masa Pandemi Covid-19. IQ (IImu Al-Qur'an): Jurnal Pendidikan Islam, 3(01), 123140.

https://doi.org/10.37542/iq.v3i01.57

Hamdani, A. R., \& Priatna, A. (2020). EFEKTIFITAS IMPLEMENTASI PEMBELAJARAN DARING (FULL ONLINE) DIMASA PANDEMI COVID19 PADA JENJANG SEKOLAH DASAR DI KABUPATEN SUBANG. Didaktik: Jurnal IImiah PGSD STKIP Subang, $\quad 6(1), \quad 1-9$. https://doi.org/10.36989/didaktik.v6i1.1 20

Hasanah, A., Lestari, A. S., Rahman, A. Y., \& Danil, Y. I. (2020). Analisis Aktivitas Belajar Daring Mahasiswa Pada Pandemi COVID-19. Karya Tulis IImiah (KTI) Masa Work From Home (WFH) Covid-19 UIN Sunan Gunung Djati Bandung Tahun 2020, 4-8.

Huda, S., Firmansyah, M., Rinaldi, A., Suherman, Sugiharta, I., Astuti, D. W., Fatimah, O., \& Prasetiyo, A. E. (2019). Understanding of Mathematical Concepts in the Linear Equation with Two Variables: Impact of E-Learning and Blended Learning Using Google Classroom. Al-Jabar: Jurnal Pendidikan Matematika, 10(2), 261270. 
Jurnal Kejaora: Jurnal Kesehatan Jasmani dan Olah Raga

ISSN: 2541-5042 (Online)

ISSN: 2503-2976 (Print)

Volume 6 Nomor 1, Edisi April 2021

https://doi.org/10.24042/ajpm.v10i2.53 03

Husdarta, H. J. S. (2009). Manajemen Pendidikan Jasmani. Bandung. Alfabeta.

Jamaluddin, D., Ratnasih, T., Gunawan, H., \& Paujiah, E. (2020). Pembelajaran Daring Masa Pandemik Covid-19 Pada Calon Guru: Hambatan, Solusi dan Proyeksi. Karya Tulis IImiah UIN Sunan Gunung Djjati Bandung, 1-10. http://digilib.uinsgd.ac.id/30518/

Mahardika, A. A. N. Y. M., \& Heryanda, K. K. (2020). Keberterimaan Dosen FE Undiksha terhadap Pemanfaatan Gawai Seluler dalam Pembelajaran Daring. Seminar Nasional Riset Inovatif, 198-206.

Marheni, E., Ridwan, M., S, A., Purnomo, E., \& Soniawan, V. (2020). Meningkatkan Gairah Belajar PJOK Siswa Pasca Pandemi Covid-19. Suluah Bendang: Jurnal Ilmiah Pengabdian Kepada Masyarakat, 20(3), 149. https://doi.org/10.24036/sb.0590

Megawanti, P., Megawati, E., \& Nurkhafifah, S. (2020). Persepsi Peserta Didik terhadap PJJ pada Masa Pandemi COVID-19. Jurnal IImiah Pendidikan, 7(2), 75-82.

Sadikin, A., \& Hamidah, A. (2020a). Pembelajaran Daring di Tengah Wabah Covid-19. Biodik, 6(2), 109-119. https://doi.org/10.22437/bio.v6i2.9759

Sadikin, A., \& Hamidah, A. (2020b). Pembelajaran Daring di Tengah Wabah Covid-19. Biodik, 6(2), 109-119. https://doi.org/10.22437/bio.v6i2.9759

Sari, D. P., \& Sutapa, P. (2020). EFEKTIVITAS PEMBELAJARAN JARAK JAUH DENGAN DARING SELAMA PANDEMI COVID-19 MATA PELAJARAN PENDIDIKAN JASMANI OLAHRAGA DAN KESEHATAN (PJOK). Pediatric Critical Care Medicine, Publish Ah, 19-29.

Simatupang, N. I., Sitohang, S. R. I., Patricia, A., Situmorang, \& Simatupang, I. M. (1981). EFEKTIVITAS PELAKSANAAN PENGAJARAN ONLINE PADA MASA PANDEMI COVID-19 DENGAN METODE SURVEY SEDERHANA. 